\title{
Perancangan Dan Simulasi Sistem Pembangkit Listrik Tenaga Surya Kapasitas 27 kWp Di Kota Cilacap
}

Bagas Gangsar Panggayuh ${ }^{1}$, Itmi Hidayat Kurniawan ${ }^{2}$

Program Studi Teknik Elektro, Universitas Muhammadiyah Purwokerto

\section{Informasi Makalah}

Dikirim, 22 Januari 2020

Direvisi, 3 Juni 2020

Diterima, 29 Juni 2020

Kata Kunci:

Fotovoltaic, Inverter, Baterai

Keyword:

Photovoltaic, Inverter, Battery

\section{INTISARI}

Pembangkit Listrik Tenaga Surya (PLTS) merupakan suatu rangkaian elektronika yang terdiri dari solar cell, penyimpan tegangan atau baterai dan power controller.Dari masing-masing komponen ini mempunyai tugas yang berbeda-beda namun saling berkaitan dalam pembangkit listrik.Pada penelitian ini dilakukan perancangan dan simulasi Pembangkit Listrik Tenaga Surya dengan kapasitas daya sebesar $27 \mathrm{kWp}$ di Kota Cilacap yang berada pada Wilayah Selatan Jawa Tengah.Potensi Pembangkit Listrik Tenaga Surya pada kawasan ini cukup potensial berdasarkan Peta Potensi Tenaga Surya rata-rata sebesar $4 \mathrm{kWp}$ per hari dan $1513 \mathrm{kWp}$ per tahun. Aspek yang harus dipertimbangkan saat merancang PLTS yaitu Perancanaan perhitungan Komponen Utama, Potensi iradiasi, Konfigurasi sistem PLTS, dan Perhitungan bebanBerdasarkan hasil simulasi PSIM untuk menentukan karakteristik V-I (Tegangan dan Arus ) dan P-V ( Daya dan Tegangan ) di dapatkan $\mathrm{V} \max =353.53 \mathrm{~V}$, Imax $=76.9 \mathrm{~A}$, Pmax $=27006.89$ Watt.Berdasarkan Hasil Simulasi ETAP untuk mengetahui analisi Aliran Daya dan Short Circuit di dapat aliran Daya yang dihasilkan photovoltaic sebesar $27+\mathrm{j} 10$ atau $27 \mathrm{KW}$ dan $10 \mathrm{kVAR}$. untuk Short Circuit Nilai arus hubung singkat pada bus 2 yakni arus keluaran dari array PV sebesar $0.236 \mathrm{kA}$.

\section{ABSTRACT}

Solar Power Generation (PLTS) is a series of electronics consisting of solar cells, voltage or battery storage and power controller. Each of these components has different but related tasks in the power plant. In this study the design and simulation of a Solar Power Plant with a capacity of $27 \mathrm{kWp}$ in the City of Cilacap in the Southern Region of Central Java was carried out. The Potential of Solar Power Plants in this region is quite potential based on the Solar Potential Map on average of $4 \mathrm{kWp}$ per day and $1513 \mathrm{kWp}$ per year. Aspects that must be considered when designing PLTS are the calculation of Main Component calculations, Irradiation Potential, PLTS system Configuration, and Load calculation. $=76.9$ A, Pmax $=27006.89$ Watt. Based on ETAP Simulation Results to determine the analysis of Power Flow and Short Circuit in the power flow generated by photovoltaic power of $27+\mathrm{j} 10$ or $27 \mathrm{KW}$ and $10 \mathrm{kVAR}$. for Short Circuit The value of the short circuit current on bus 2 is the output current from the PV array of $0.236 \mathrm{kA}$. 


\section{Korespondensi Penulis:}

Bagas Gangsar Panggayuh

Program Studi Teknik Elektro

Fakultas Teknik dan Sains Universitas Muhammadiyah Purwokerto

JL. Raya Dukuhwaluh, Purwokerto, 53182

Email: lumbonperiangan@gmail.com

\section{PENDAHULUAN}

Kebutuhan akan listrik baik untuk kalangan industri, perkantoran, maupun masyarakat umum dan perorangan sangat meningkat. Tetapi, peningkatan kebutuhan listrik ini tidak diiringi oleh penambahan pasokan listrik.Berdasarkan permasalahan tersebut, energi surya dipilih sebagai energi alternatif untuk menghasilkan energi listrik. Alat yang digunakan disini adalah sel surya, karena dapat mengkonversikan langsung radiasi sinar matahari menjadi energi listrik[1].

Sistem PLTS dapat diwujudkan dengan tersedianya beberapa komponen pendukung yaitu panel surya, penyimpan energy, rangkaian system pengisi baterai serta rangkaian inverter yang mengubah listrik DC ke AC, dengan proses perencanaan terlebih dahulu. Dalam perencanaan, hal-hal yang harus diperhitungkan adalah besar kapasitas daya listrik, rerata waktu penyinaran matahari serta system jaringan listrik yang akan diwujudkan[2][3]. Sebelum system diwujudkan, maka akan lebih jika dilakukan proses simulasi, karena dalam simulasi akan tergambar hal-hal yang dibutuhkan dalam penerapan nyata, serta kendala-kendala yang mungkin muncul juga dapat diantisipasi [4]. PLTS atau lebih dikenal dengan sel surya (SelPhotovoltaic) akan lebih diminati karena dapat digunakan untuk berbagai keperluan yang relevan dan diberbagai tempat seperti perkantoran, pabrik, perumahan, dan lainnya. Dalam penelitian ini akan dianalisis perancangan dan simulasi sistem pembangkit listrik tenaga surya kapasitas $27 \mathrm{kWp}$. Dengan tujuan untuk mengkaji unjuk kerja sistem pembangkit tenaga listrik tenaga surya $27 \mathrm{kWp}$ di kota Cilacap.

\section{METODE PENELITIAN}

Langkah-langkah yang dilaksanakan dalam penelitian ini adalah sebagai berikut

1. Studi literatur.

2. Perencanaan Sistem Pembangkit Listrik Tenaga Surya kapasitas 27 kWp.

3. Pemodelan dan simulasi Panel Surya.

4. Analisa sistem Tenaga Listrik pada PLTS yang terhubung dengan Beban

5. Analisa Unjuk Kerja Sistem yang meliputi Analisis Aliran Daya,

\section{HASIL DAN PEMBAHASAN}

\subsection{Potensi Energy Matahari untuk Wilayah Kota Cilacap Selatan.}

Studi kelayakan untuk mengetahui Potensi iradiasi suatu wilayah juga dapat dilakukan Menggunakan data satelit atau data terdahulu seperti data NASA atau SolarAtlas (http://globalsolaratlas.info/).Pada penelitian ini dilakukan studi potensi energy matahari untuk wilayah Kota Cilacap Selatan.

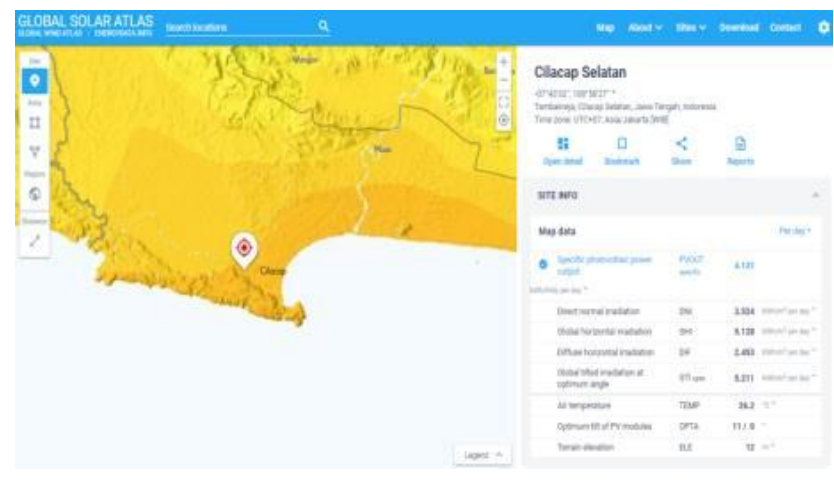

Gambar 1. Potensi Energi Matahari wilayah Kota Cilacap 
Berdasarkan studi potensi iradiasi energimatahari untuk wilayah Kota Cilacap dengan spesifikasi pembangkit energi listrik dengan kapasitas $27 \mathrm{kWp}$, dengan tingkat kemiringan Panel antara $0-11^{\circ}$ memiliki potensi pembangkitan energy listrik sebesar $111.537 \mathrm{kWh} / \mathrm{m}^{2}$ per day.

\subsection{Simulasi Array PV Kapasitas 27 kW Dengan Menggunakan PSIM}

Array PV dengan kapasitas $27 \mathrm{~kW}$ ini terdiri 3 kelompok array PV, masing-masing array PV terdiri dari 3 string yang terhubung secara paralel dan tiap-tiap string ini terdiri dari 10 modul PV yang terhubung secara seri dan sebuah inverter.

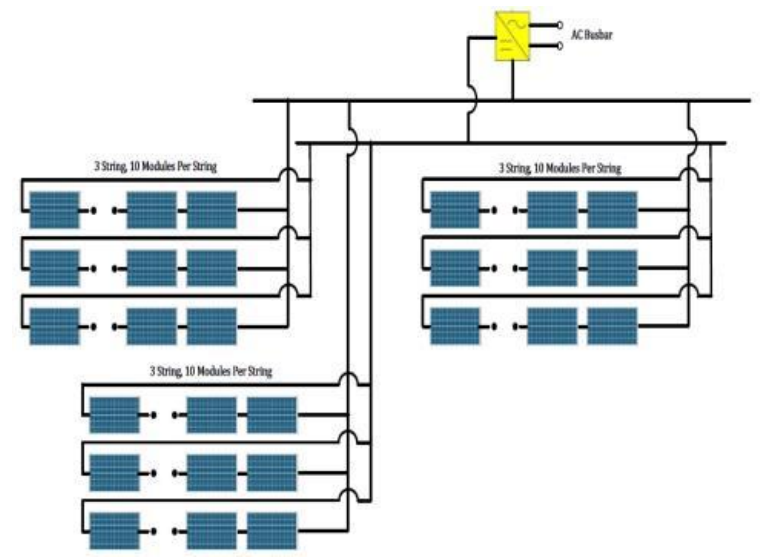

Gambar 2. Sistem array PV

\subsection{Hasil Simulasi Array PV Kapasitas 27 kW}

Hasil simulasi PSIM ini berupa kurva yang menunjukkan hubungan antara arus-tegangan, daya keluarantegangan dan daya keluaran-arus Daya keluaran maksimum $\left(P_{\max }\right)$ yang mampu dicapai adalah 27.007W, sedang besarnya arus saat $P_{\max }$ yaitu 76.39 A dan tegangan saat $P \max$ yaitu $354 \mathrm{~V}$. Simulasi ini dilakukan dengan kondisi operasi intensitas cahaya $S=1000 \mathrm{~W} / \mathrm{m}^{2}$ dan suhu lingkungan $T_{a}=25$

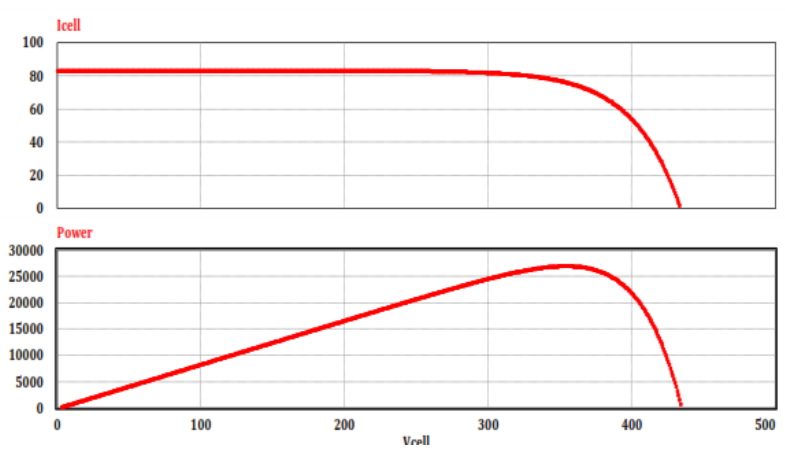

Gambar 3.Kurva hubungan antara I-V danP-V array PV $27 \mathrm{~kW}$

\subsection{Simulasi Analisis Aliran Beban dan Hubung singkat dengan menggunakan ETAP}

Perangkat lunak ETAP untuk studi aliran beban (load flow) dan hubung singkat (short circuit) didasarkan atas model single line diagram (SLD). Diagram ini merepresentasikan sistem tenaga listrik dari sumber tenaga listrik ke pengguna listrik.Penelitian ini memiliki sumber tenaga listrik berupa PLTS dan baterai, sedang pengguna listriknya dapat didefinisikan sebagai beban statis untuk keperluan rumah tangga dan penerangan jalan. Analisis aliran beban pada pada penelitian ini dilakukan untuk mengetahui aliran daya aktif maupun reaktif, aliran arus dan tegangan di setiap percabangan jaringan listrik, sedang analisis hubung-singkat dilakukan untuk menginvestigasi kemampuan pemutusan dan menahan arus hubung singkat dari peralatan pelindung. Model SLD yang diimplementasikan ke ETAP. 


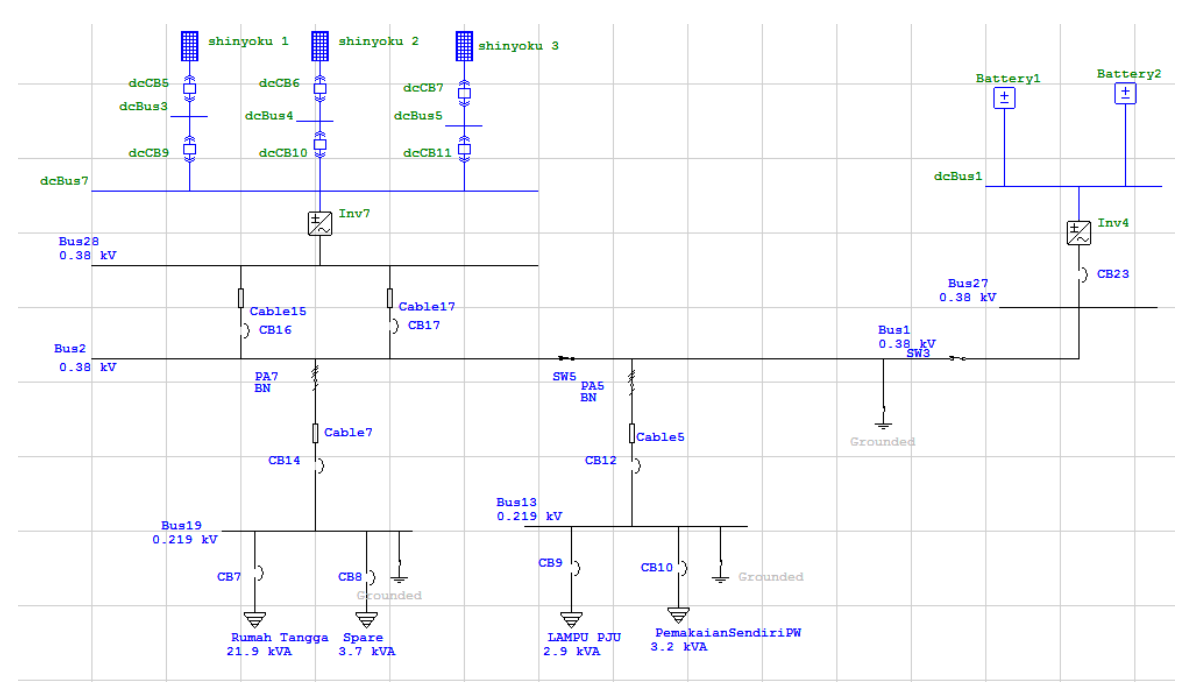

Gambar 4. Model SLD sistem tenaga listrik yang akandisimulasikan

\subsection{Analisis Aliran Daya}

Simulasi yang dilakukan, hasil yang didapatkan menunjukkan bahwa besarnya daya yang dihasilkan photovoltaic sebesar $27+\mathrm{j} 10$ atau $27 \mathrm{KW}$ dan $10 \mathrm{kVAR}$ dan Daya komplek

$$
\begin{aligned}
\mathrm{S} & =\sqrt{\mathrm{P}^{2}+\mathrm{Q}^{2}} \\
\mathrm{~S} & =\sqrt{ } 27^{2}+10^{2} \\
\mathrm{~S} & =\sqrt{ } 829 \\
& =28.79 \mathrm{Kva}
\end{aligned}
$$

sehingga untuk beban 1 sebesar $25.6 \mathrm{kVA}$ disuplai dari etap sebesar $22+\mathrm{j} 8$ atau $22 \mathrm{KW}$ dan $8 \mathrm{kVAR}$. Sedangkan, beban 2 dengan kapasitas $6.1 \mathrm{kVA}$ disuplasi daya sebesar $5+\mathrm{j} 3$ atau $5 \mathrm{KW}$ dan $3 \mathrm{kVAR}$.

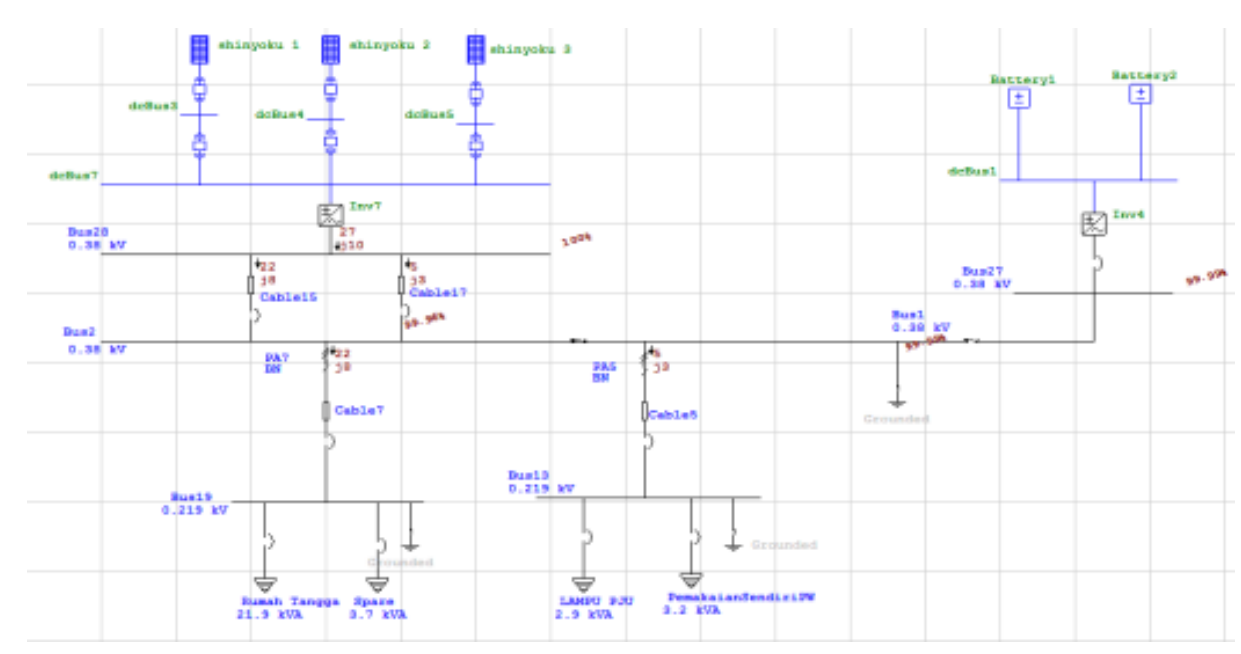

Gambar 5. Hasil running simulasi analisis daya ETAP

Hasil laporan analisis aliran daya didapatkan seperti Gambar dibawah.Hasil simulasi menunjukkan bahwa pada bus 1 mengalirkan $5 \mathrm{~kW}$ dan $3 \mathrm{kVAR}$. Arus yang mengalir pada bus 1 sebesar 9.2 A dengan nilai faktor dayanya sebesar 0.909 dan bus 2 mengalirkan $22 \mathrm{~kW}$ dan $8 \mathrm{kVAR}$. Arus yang mengalir pada bus 2 sebesar 34.7 A dengan nilai factor dayanya sebesar 0.944 


\subsection{Studi Hubung-Singkat Dengan Menggunakan ETAP}

Tabel 1. Rangkuman nilai arus maksimal saat terjadi hubung-singkat

\begin{tabular}{lllc}
\hline Jenis Gangguan & 3-Phase & Line to Line & Line to Line Ground \\
\hline Nilai & $0.236 \mathrm{kA}$ & $0.205 \mathrm{kA}$ & $0.236 \mathrm{kA}$
\end{tabular}

Arus hubung singkat dari beban terbesar yang terpasang ke array PV sebesar 98.63 A dihitung dengan persamaan berikut,

$$
I s c=\frac{\operatorname{In} \times 100}{U n}=\frac{116,7 \times 100}{380}=0.307 \mathrm{kA}
$$

Arus hubung singkat yang didapat dari simulasi tidak lebih dari arus analisis perhitungan.Hal ini menunjukkan bahwa spesifikasi dari array PV yang digunakan untuk perancangan real tidak mengalami gangguan pada peralatan tersebut saat terjadi hubung-singkat.

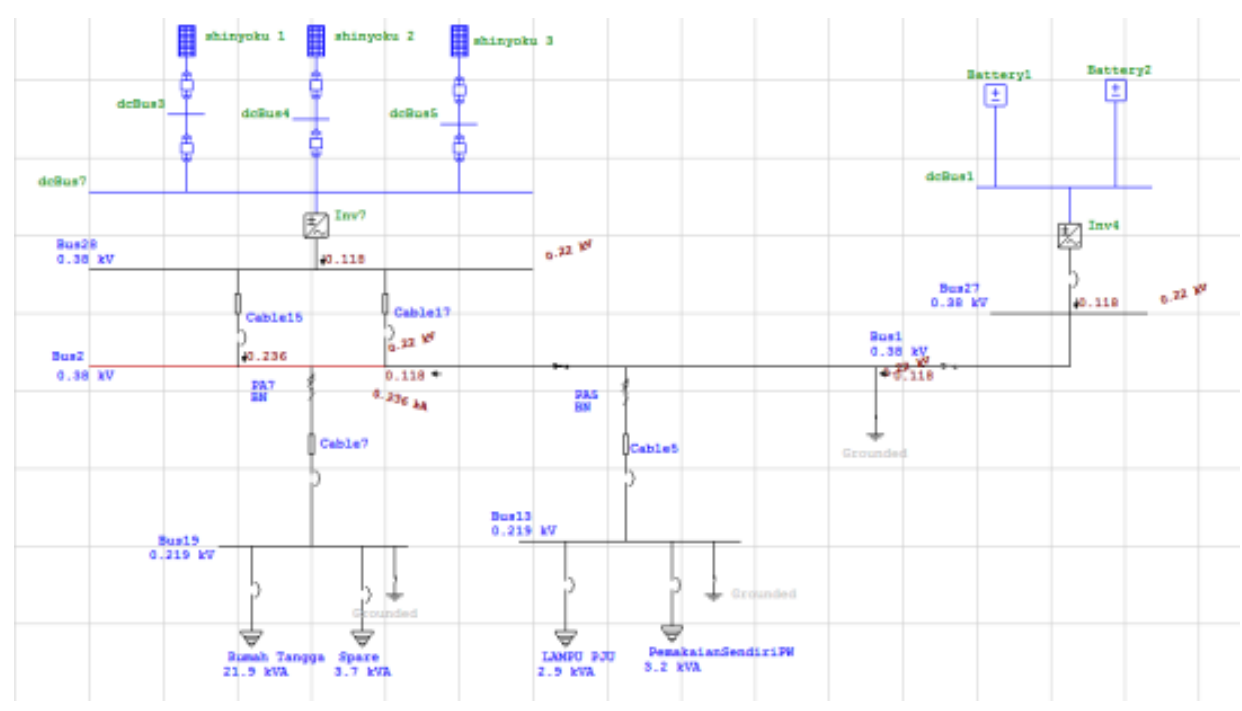

Gambar 6. Hasil running simulasi hubung-singkat ETAP

\section{KESIMPULAN}

Dari hasil perancangan dan simulasi, dapat diambil beberapa kesimpulan, diantaranya adalah:

1. Perancangan PLTS sistem Off Grid dengan menggunakan 90 modul panel surya Polycrystalin 300 Wp, 2 Buah Inverter Merk Solar Central 55 Kw, dan 24 buah battery 2 V 2000 Ah.

2. Untuk merencanakan PLTS $27 \mathrm{kWp}$, dibutuhkan modul surya sebanyak 90 unit, dengan susunan modul seri sebanyak 10 modul, dibagai menjadi 3 group, menghasilkan tegangan 360 volt, dan arus $74.52 \mathrm{~A}$, dengan daya maksimum $26.8 \mathrm{kWp}$

3. Dengan intensitas matahari rata-rata sebesar $4.131 \mathrm{kWh} / \mathrm{m} 2 /$ day, PLTS mampu memproduksi listrik sebesar $111.537 \mathrm{kWh} /$ day.

4. Nilai arus hubung singkat pada bus 2 yakni arus keluaran dari array PV sebesar $0.236 \mathrm{kA}$. Hal ini dapat menjadi bahan pertimbangan dalam pembuatan peralatan secara riil, karena arus hubung singkat secara perhitungan analisis sebesar $0.307 \mathrm{kA}$.

5. 5. Analisis sistem tenaga listrik yang dihasilkan dari 90 Panel Surya $300 \mathrm{Wp}$ besarnya daya yang dihasilkan photovoltaic sebesar $27+\mathrm{j} 10$ atau $27 \mathrm{KW}$ dan $10 \mathrm{kVAR}$ dan Daya Semu $28.79 \mathrm{kVA}$ 


\section{DAFTAR PUSTAKA}

[1] Anwar Ilmar Ramadhan, Ery Diniardi dan Sony Hari Mukti, Analisis Desain Sistem Pembangkit Listrik Tenaga Surya Kapasitas 50 WP, Teknik, 2016, Vol 37(2), hal 59-63

[2] Elena, Ciprés L. 2011. Analysis Of Theimplementation Of a Photovoltaic Plant In Catalonia. Master Thesis Politechnica Lodzka, 2011

[3] Muhammad Hariansyah, Studi Perencanaan Pembangkit Listrik Tenaga Surya (PLTS) Kapasitas 25 kWp, Elektriese, 2009, Vol 1 No 1

[4] PutuYudiA.P, Perancangan Dan Pembuatan Simulasi Pembangkit Listrik Tenaga Surya (PLTS), Laporan Tugas Akhir, Jurusan Diploma Iii Teknik Elektro Fakultas Teknik Dan Kejuruan Universitas Pendidikan Ganesha Singaraja, 2007 